\title{
TESTA@Greenwich - engaging students in feedback and assessment
}

\author{
Duncan McKenna \\ University of Greenwich
}

TESTA@Greenwich is a research project which investigates assessment and feedback at the programme level. The methodology uses data both quantitative (a tailored questionnaire and an audit of programme Feedback \& Assessment - F\&A - structures) and qualitative (student focus groups); this is then collated into a holistic case study of F\&A on individual programmes, to be fed into the periodic review process. Data are collected by students and come directly from students and staff, creating a powerful and insightful picture of feedback and assessment structures from stakeholders on both sides of the learning journey.

"Students ought to be engaged with their learning experience." It is a sentence we have all heard in some educational context. In fact, the word 'engagement' has become a by-word for so many things surrounding the student experience, that it is sometimes difficult to know which field of student life it refers to; this is a troublesome predicament, given that student engagement is key to so many HE agendas and, indeed, to the whole concept of a satisfactory learning experience.

Students ought to be engaged with the material they are being asked to learn, so that they go beyond a surface approach and begin to absorb a holistic understanding of their discipline, and further, with the skills which that discipline imparts, in order to aid their graduate life (Fletcher, 2012). They ought to be engaged with their peers and members of academic staff, so that they build the relevant social/professional skills and networks for later life. Learning therefore becomes a partnership: a pro-active, shared experience where ideas are the key commodity (Coates, 2007). Students ought to be engaged with the way they are taught and assessed, not only the better to understand their learning outcomes, but also to help to shape an enhanced education for future cohorts (HEFCE, 2008).

TESTA@Greenwich is concerned with all of the above, as it engages students in research, both as participants and researchers. However, most crucially, we believe that students must be involved in shaping the way that they are taught, assessed and given feedback, so that they may take advantage of the goldmine of critical thinking and innovative suggestions for improvement that come from their direct experience.

Students are full of bright ideas - it is their job to think. The wealth of resources presented every year at Jisc's 'Summer of Student Innovation' testifies to that on a national scale, and University of Greenwich students, have a lot to offer in terms of innovative design, not merely technologically, but pedagogically too, as evidenced at our focus groups: a new approach to the submission system for pieces of work; using a two-stage deadline to incorporate peer feedback into the standard submission process; and ideas on how to provide lecturers with the chance to see the capabilities of their students in self-assessment and improvement. Creativity and functionality are clearly evident, yet there is a disjunction between this level of creative thinking/engagement, and the number of opportunities students are given to exhibit them. We should open our ears, even more than we do now, to take advantage of this level of imagination. 
TESTA@Greenwich looks primarily into feedback and assessment, which is what the students are most concerned about and what student satisfaction surveys constantly highlight as in need of improvement. Our initial analysis of findings from focus group interviews and questionnaires from eight programmes undergoing TESTA mirrored the worries students expressed in the NSS and highlighted aspects especially problematic for Greenwich. It revealed that students: are generally unhappy with the way their learning goals have been communicated to them; do not see value in exams as a learning tool; experience difficulties with comprehending the language of the feedback they receive; often approach assessments without fully understanding what they are learning. While the initial results vary across the programmes, the fact that many of these concerns had some positive mirrors from the same cohorts may imply that communication, and not just practice, is also at stake.

Creating a narrative and a dialogue with students about their assessment and feedback diet is absolutely key. Speaking to students and having them speak to us, creating an open and continuous free flow of ideas, is an ideal that TESTA@Greenwich strives for and what we hope our research will achieve.

What's more, we believe that working directly with students in a partnership is vital to the success of any process of student engagement and therefore to the success of any modern university. As Dunne states:

'There is a subtle, but extremely important, difference between an institution that 'listens' to students and responds accordingly, and an institution that gives students the opportunity to explore areas that they believe to be significant, to recommend solutions and to bring about the required changes." (Dunne, in Foreword to Dunne and Zandstra, 2011)

TESTA delves deeper than student satisfaction surveys, penetrating the layer of student engagement. Drawing on theoretical thinking behind the concept of student involvement (Neary, 2012; Bovill, 2011; Healy, 2009), TESTA is working with five students (four of them on a scholarship), harnessing their skills as 'Student as Change Agents'. Their role is to create a bridge between us, the staff, and the student body; by operating outside the conventional channels of staff/student communication and by using their first-hand knowledge of what concerns students, they will, we hope, enable us to draw both sides closer to each other and to begin building a sustainable structure for student engagement, with students closely involved in assessment and feedback innovation, as both means and end. We also hope that TESTA will provide sufficient data for the Student Change Agents to act as a representation of the student voice, successfully to communicate concerns to staff and to suggest innovative and pragmatic solutions to those problems.

Empowering students to engage with the way they are taught (and especially with assessment and feedback), teaching them to learn as well as what to learn and giving them ownership of, and the ability to construct, their own educational experience: all these are what we aspire to achieve through TESTA. Students are full of bright ideas - and we want to listen.

For more information visit:

www.testa.ac.uk

blogs.gre.ac.uk/testa 


\section{Reference list}

Bovill, C, Cook-Sather, A, and Felten, P. (2011) 'Students as co-creators of teaching approaches, course design, and curricula: implications for academic developers.' International Journal for Academic Development, 16(2), 133-145.

Coates, H. (2007) 'A Model of Online and General Campus-Based Student Engagement.' Assessment and Evaluation in Higher Education, 32 (2), 121-141.

Dunne, E and Zandstra, R. (2011) Students as change agents - new ways of engaging with learning and teaching in higher education. Foreword, p.4. Bristol: A joint University of Exeter/ESCalate/Higher Education Academy Publication. Available at: http://escalate.ac.uk/8064 (Accessed: 5 March 2014).

Fetcher, A. (2012) 'Convenient or inconvenient student voice?' Connect Vol. 2012:194.

Healy, M. (2009) 'Developing the student as a researcher through the curriculum.' In: Rust, C. (ed.) Improving Student Learning through the Curriculum, Oxford Centre for Staff and Learning Development, Oxford Brookes University, Oxford: OCSLD

HEFCE (2008) Tender for a Study into Student Engagement. Bristol: Higher Education Funding Council for England.

Neary, M. (2012) 'Student as Producer: An Institution of the Common? [or, How to Recover Communist/Revolutionary science].' Enhancing Learning in the Social Sciences, Higher Education Academy, York. Available at:

http://www.heacademy.ac.uk/assets/documents/disciplines/socialsciences/ELiSS0403A_Guest_paper.pdf (Accessed: 5 March 2014). 